\title{
Digital Consumers in the Foodservices Market
}

\author{
Iwona Kowalczuk $^{1}\left(\mathbb{D}\right.$, Dagmara Stangierska ${ }^{2}{ }^{\mathbb{D}}$, Jerzy Gębski ${ }^{1} \mathbb{D}$, Agnieszka Tul-Krzyszczuk ${ }^{3, *(\mathbb{D})}$ \\ and Edyta Zmudczyńska ${ }^{4}$
}

1 Institute of Human Nutrition Sciences, Warsaw University of Life Sciences (SGGW-WULS), Nowoursynowska 159C, 02-776 Warsaw, Poland; iwona_kowalczuk@sggw.edu.pl (I.K.); jerzy_gebski@sggw.edu.pl (J.G.)

2 Institute of Horticultural Sciences, Warsaw University of Life Sciences (SGGW-WULS), Nowoursynowska 159, 02-776 Warsaw, Poland; dagmara_stangierska@sggw.edu.pl

3 Institute of Management, Warsaw University of Life Sciences (SGGW-WULS), Nowoursynowska 161, 02-787 Warsaw, Poland

4 College of Agriculture and Natural Resources, National Chung Hsing University, 145, Xingda Road, South District, Taichung City 40227, Taiwan; e.zmudczynska@gmail.com

* Correspondence: agnieszka_tul_krzyszczuk@sggw.edu.pl; Tel.: +48-2259-37-012

Citation: Kowalczuk, I.; Stangierska, D.; Gębski, J.; Tul-Krzyszczuk, A.; Zmudczyńska, E. Digital Consumers in the Foodservices Market. Sustainability 2021, 13, 7403. https:// doi.org/10.3390/su13137403

Academic Editors: Hyeon-Mo Jeon, Hyung-Min Choi and Hye Jin Sung

Received: 11 June 2021

Accepted: 28 June 2021

Published: 1 July 2021

Publisher's Note: MDPI stays neutral with regard to jurisdictional claims in published maps and institutional affiliations.

\begin{abstract}
The dynamic development of e-commerce in the foodservice market has been observed in recent years (especially during the COVID-19 pandemic), both in Poland and in other countries. The purpose of the study was to determine the characteristics of e-foodservice customers, identify their motivations for ordering food online and the nutritional consequences of such actions, as well as recognize the influence of consumers' s-commerce activity on their foodservice market behavior. The study was carried out using the CAWI method on a sample of 1018 adult Poles. With the use of cluster analysis, three consumer segments were distinguished: frequent e-commerce users (221), moderate users (400), and sporadic users (397). The results indicate that frequent users of e-commerce in the foodservice market are slightly more often young and educated men who work full-time, have a higher than average income, and live in a large or medium city. In their own opinions, frequent users are the most concerned about proper nutrition, but despite such declarations, their nutritional quality is inferior to other groups. Compared to other segments, they are the most socially active and show the greatest commitment to s-commerce activity, which influences their purchasing intentions and behaviors.
\end{abstract}

Keywords: e-consumer; foodservice market; e-commerce; s-commerce; quality of nutrition

\section{Introduction}

Information and communication technologies stimulate changes in many areas of the economy, including the services sector [1], being an important factor in their development [2]. This also applies to the foodservices market [3]. Thanks to widespread Internet access, the development of the telecommunications industry, and the software to support the services provided, numerous catering companies now allow customers to view their offers, make reservations, or place orders online [4].

The development of technology also inspires innovation in offered services, which is one of the conditions for competitiveness [5]. According to Slack et al. [6], service companies compete in the market in five key areas: quality, cost, speed, reliability, and flexibility. Previous studies on the use of modern technologies in hospitality and food services have proven their positive effects on the quality of services [7,8], speed of service provision [9], reliability $[10,11]$, cost control $[12,13]$, and the company's image building, as well as the flexibility of operation and employee training [14].

Progressing digitalization also stimulates customer behavioral changes [15], and shapes the information society [16], wherein the level of technical and organizational development is so notable that it creates technical, economic, educational, and other 
conditions for the widespread use of information in the production and consumption of both material goods and services [17]. The integration of social media and social networking elements with the process of buying and selling products and services on an online platform is called s-commerce. This construct includes elements such as reviews, ratings, comments, etc., which influence trust and online decision-making processes [18].

From the point of view of producers and service providers, getting to know the characteristics of e-commerce market customers, as well as their needs and preferences, is crucial in creating a short- and long-term strategy for the business. Nevertheless, while the literature offers much information about the characteristics of the e-buyer of material products, the e-buyer of services, including food services, is poorly identified.

It should be emphasized that in the foodservice market, apart from the marketing context, the health aspect of e-customers' behavior is also essential. Research conducted so far shows that the use of catering services may have an adverse effect on the health of the individuals and, consequently, the entire population [19-22]. According to Todd et al. [23] consumers have strong preferences for less healthy food when dining away from home. In turn, Stephens et al. [24] draw attention to the adverse health effects of the widespread use of food delivery apps, resulting from the specific selection of dishes offered through these applications.

It should also be noted that year after year, foodservice enterprises are becoming an increasingly important element of the food system. Striving to achieve the objectives of sustainable development, we cannot therefore marginalize their impact on the manner and quality of the nutrition of people using (also in the form of e-services) foodservice offerings [24].

These observations indicate the necessity of conducting a multifaceted analysis that will help understand the behavior of e-customers in the foodservices market. This is more important because over the past year, due to the COVID-19 pandemic, there has been a rapid growth in e-commerce in the catering market, especially in the area of online delivery orders [25]. A significant increase in consumer interest in such services was also observed [26]. Moreover, it is predicted that even once stationary dining services are available again, the use of online orders will be more common than before the pandemic [27].

The aim of the conducted study was to fill the existing research gap regarding the characteristics of e-consumers in the foodservice market. The authors intended to determine the demographic, economic, social and lifestyle profile of e-foodservice customers, recognize their motivations for ordering deliveries online, identify the relationship between frequency of ordering food online and the quality of nutrition, as well as recognize the influence of consumers s-commerce activity on their purchasing intentions and behaviors.

The paper consists of seven parts. In the introduction (part one) the rationale for the choice of the issue of the research work undertaken and its purpose are presented. The literature review (part two) addresses issues such as the characteristics of the e-consumer, e-service consumer and e-foodservice consumer, the impact of s-commerce development on consumer behavior in the foodservice market, and the development of e-commerce in the Polish foodservice market. On this basis, research hypotheses were formulated (part three). The methodological part (four) presents information about the course of the study, the construction of a research questionnaire and the methods of statistical analysis used. In presenting the results of the study (part five), the frequency of consumers' use of various forms of e-commerce is discussed, and the consumer segments distinguished on this basis are characterized. The discussion Section 6, compares the results obtained with the results of other studies, while the conclusion, Section 7, presents a brief summary of the results and conclusions of the study, as well as the strengths and limitations of the study and suggestions for future analyses. 


\section{Literature Review}

\subsection{Characteristics of the E-Consumers, E-Service Consumers and E-Foodservice Consumers}

As stated in the introduction, the characteristics and behaviors of e-consumers have been broadly analyzed in literature (especially from 1990 to 2000). The analyses included aspects such as the frequency of shopping [28-31], demographic and social characteristics of consumers [28,32], and psychological aspects of purchasing behavior [28,33-35], including reasons for purchasing [33,36] and risk perception [37-39]. The research also examined technical and organizational concerns related to the implementation of purchases, such as the interface, design and navigation of websites [40], ease of shopping [41], or payment methods [42].

Prior studies on the characteristics of e-customers have demonstrated that they are more frequently young people [43] with higher education $[44,45]$ and higher economic status [46]. E-consumers are also prone to innovation [47], and, when making their purchases, they are primarily driven by convenience [48-50]. Freedom of choice and time-saving are also crucial to them [48].

The pleasure experienced while shopping is also an essential motivation for consumers to purchase online. Kim [49] and Kim and Peterson [50] found that it is crucial to determine the acceptance and propensity to use new technologies by consumers, apart from the convenience and ease of shopping. In turn, according to Parasuraman [51], the important condition for using new technologies is the technological readiness of consumers, in other words "the individual's willingness to adopt and use new technologies". Research on this matter suggests that an individual may simultaneously present both positive and negative technological beliefs, and the balance between them determines their predispositions to accept or reject a new technology [52].

The studies conducted so far have also shown that e-consumers' behavior is determined by economic factors as well, specifically the competitive prices of purchased goods [53] and other economically measurable benefits obtained as a result of shopping online, such as participation in loyalty programs [54].

Technical and technological aspects, such as the website design $[33,55,56]$ and the efficiency of its operation [55], are also a vital determinant of e-shopping behavior. The research by Aren et al. [57] showed that a user friendly website significantly increases consumers' willingness to purchase online.

In scientific research, there have also been many attempts to sort e-consumers into segments. In the study conducted by Donthu at al. [58], e-consumers of electronic products were assigned to segments based on sociodemographic variables and selected aspects of attitudes. When describing the e-consumer segments in Greece's electronic products market [45], demographic and behavioral characteristics were taken into consideration, distinguishing current and potential buyers. In a study conducted by Brown et al. [32], six groups of consumers were distinguished after considering their intention to buy. Kau et al. [59] identified six consumer segments after analyzing information seeking patterns, motivations, and online shopping concerns. Based on motivation to purchase, Rohm and Swaminathan [60], identified four e-customer profiles: convenience shoppers, variety seekers, balanced buyers, and store oriented shoppers. Two segments of supermarket e-customers in Spain were characterized by Cristóbal et al. [61], taking into account both the website's design and the processes when making the purchase.

As far as e-service commerce is concerned, previous research into the characteristics and behavior of customers are limited. Studies show that consumers use online services mainly because of convenience and usefulness, and an important reason for usage of online services is good prior online experiences [62].

Based on the authors' knowledge, only one research [63] on this subject has been published so far. The results indicated that $15 \%$ of adults across Australia, Canada, Mexico, the UK, and the USA had purchased prepared meals through online food delivery services in the past 7 days. Online food delivery service use was associated with being male, from an ethnic minority, younger, highly educated, or living with children under 18. 
Sociodemographic characteristics of online food delivery customers were consistent across countries, yet there was variation in the strength of associations.

\subsection{S-Commerce Development and Its Influence on E-Consumer Behavior in the Foodservice Market}

A significant influence on consumer behavior in the foodservice market has been the development of social commerce, initiated in 2008 by the emergence of Groupon [64]. According to many researchers [65-70], the areas of e-commerce and s-commerce are complementary, and the difference between them is that the first mainly focuses on individuals and direct interactions to create value, while the second involves communities and interactions among members.

In the process of social interaction, consumers can recommend and evaluate products, exchange shopping information, knowledge and opinions, as well as obtain opportunities to trade [71-75]. Clients in the foodservice market seem to tend to pay even more attention to online reviews because the full specifics of the service offer are not available before the point of consumption [72]. In this regard, online reviews play an important role in reducing the risk related to market choices [76]. Online worth of mouth (WOM) is widely accepted as the most reliable and influential information to describe a dining experience $[72,75,77]$. Research on this issue noted that factors such as the source of the reviews, ratings level, and the number of reviews increase consumers' trust in online opinions [74].

It was also noticing that using social commerce and engaging clients in WOM behavior increases their loyalty, generates supplemental revenue, and reduces operating costs for service providers $[78,79]$.

\subsection{E-Commerce in Poland in the Foodservice Market}

Poland has relatively low levels of information and communication technologies development, as evidenced by the DESI (The Digital Economy and Society Index developed by the European Commission is an index that assesses the development of EU countries in the field of digital economy and society. It aggregates a set of five factors concerning: connectivity, human capital, use of the internet, integration of digital technologies, and digital public services https:/ / ec.europa.eu/digital-single-market/en/desi, accessed on 10 December 2020). In 2019, Poland ranked 25th among the European Union countries, with an indicator of 43.0 (with an average of 54 for all EU countries) [80]. Nevertheless, a growing interest in ICT can be observed among Polish consumers, year by year, which is reflected in the increasing share of people using the Internet-from $67.6 \%$ in 2012 to $81.7 \%$ in 2018. These statistics are expressed in the number of people buying online-between 2012 and 2018, the percentage of people ordering goods and services online for private consumption increased by 18.2 percentage points (from $40.0 \%$ to $58.2 \%$ ), with a majority of Poles declaring shopping online for clothes (64\%), books and CDs (54\%), cinema and theater tickets (51\%), food (46\%) and shoes (44\%) [81]. A slightly smaller increase was recorded in searches for information about goods or services $(64.0 \%$ in 2018 , compared to $47.5 \%$ in 2012) [82].

Consumers' growing interest in modern technologies is also reflected in their behavior in the catering services market. It is a result of increasing incomes, the development of tourism, demographic changes (an increase in the number of single and double households), as well as generational changes, such as the introduction of Generation $\mathrm{Z}$ into the market (not only for catering) - the use of catering services is an essential element of the lifestyle of this group [83,84].

In Poland, as in other countries [28,85], the increasing interest among consumers regarding orders with delivery plays an essential role in the catering sector's development. In response to the demand, many restaurants have started offering online food delivery. Several online food delivery platforms (e.g., UberEats, PizzaPortal, Pyszne.pl) have also emerged, serving a variety of functions, such as providing consumers with a wide choice of dishes, taking orders and relaying them to the food producer, monitoring payments, organizing food delivery and the provision of tracking facilities. The online food delivery 
industry has been very proactive in the way it develops new markets and cultivates consumers' eating habits [86]. Another solution to attracting consumers to use the food delivery services are mobile apps, which greatly facilitate the ordering process [70].

According to the "Food service market report" [87], the Polish online food ordering market is growing at a rate of approximately $50 \%$ annually (i.e., much faster than the entire e-commerce market, which can only boast a turnover growth of approximately $15-20 \%$ annually), and its value in 2020 was estimated at PLN 1 billion. The value of the average basket of online orders was approximately 30-50 PLN (EUR 8-12). Recent research shows that the COVID-19 pandemic has had a significant impact on consumer behavior in the foodservice market, with as many as $81 \%$ of Poles visiting stationary foodservice establishments less often, and over a third more likely to order food online, with men and 18-24 year olds doing so more often [88]. The report "Poland on a plate" [89] showed that the most frequently ordered online dish was pizza (61\%), while American dishes $(22 \%)$, Asian dishes and sushi $(8 \%)$, Arabic dishes (6\%), and Polish dishes (3\%) were less popular. Interestingly, an analysis of the culinary preferences of Poles shows that the most frequently chosen dishes in gastronomic enterprises are Polish (82\%), Italian (69\%), and American (36\%). It was also noticed that, for Polish consumers, the most crucial factors when ordering online were the quality of the dishes (38\%), delivery time (37\%), restaurant's reliability (35\%), good service (31\%), and easy ordering (29\%) [90].

Nevertheless, Poland's position in terms of market value and the percentage of people using online food ordering is far behind other countries. Statista [91] estimates that the value of the Polish online ordering market in 2020 was close to USD 500 million, which places Poland at 25 th position in the global ranking. As for user penetration in online food delivery, it is $18.7 \%$, which ranks Poland at only 40 th.

\section{Hypothesis of the Study}

In the context of the information presented in the literature review, as well as the authors' own observations and experiences, five research hypotheses were formulated:

Hypothesis 1 (H1). The demographic, economic, and social profile of a frequent foodservices ecustomer is similar to the characteristics of a typical e-consumer, which means that they are a young, educated person, more often male, with middle-to-high income, living in a large or medium-sized city.

Hypothesis 2 (H2). The most commonly used form of e-commerce offer on the foodservice market is ordering food online.

Hypothesis 3 (H3). The main reason for using online orders by frequent foodservice e-customers is convenience, while the primary limitations are technical issues related to problems with internet access and the lack of communication devices.

Hypothesis 4 (H4). Frequent e-foodservice users, in comparison with moderate and sporadic users, are the most socially active and the most committed to s-commerce activities.

Hypothesis 5 (H5). Due to the fact that the gastronomic offer available online is predominantly fast food, frequent users are characterized by an inferior quality of nutrition.

\section{Methodology}

\subsection{Data Collecting}

Considering the purpose of the study and the formulated research hypotheses, a survey questionnaire and research methodology were developed, the implementation of which was entrusted to a professional research company. To select the respondents, quota sampling was used (i.e., the structure of the study sample was the same as the population of Poland in terms of gender, age and place of residence). The ethical aspects followed throughout the study ensured the continued safety of participants as well as the integrity 
of accumulated data. A brief description of the study and its aim, and the declaration of anonymity and confidentiality, were given to the participants before they filled in the questionnaire. Respondents did not provide their names or contact information (including IP address), and could finish the survey at any stage. The data were collected for two months using the CAWI (computer assisted web interview) method.

The study was carried out on a sample of 1018 people. The characteristics of the respondents are displayed in Table 1.

Table 1. Characteristics of the study population.

\begin{tabular}{|c|c|c|}
\hline \multicolumn{3}{|c|}{ Age (Years) Average $39.67\left(\mathrm{SD}^{*}=12.46\right)$} \\
\hline Sex & $n$ & $\%$ \\
\hline Woman & 533 & 52.36 \\
\hline Man & 485 & 47.64 \\
\hline Place of residence & $n$ & $\%$ \\
\hline Rural & 396 & 38.90 \\
\hline Town up to 50,000 residents & 68 & 6.68 \\
\hline City, $50,000-100,000$ residents & 229 & 22.50 \\
\hline City, over 100,000 residents & 325 & 31.93 \\
\hline Income & $n$ & $\%$ \\
\hline Up to 1500 PLN (324 EUR) ** & 196 & 19.27 \\
\hline 1501-2500 PLN (324-540 EUR) & 312 & 30.68 \\
\hline 2501-3000 PLN (540-648 EUR) & 207 & 20.35 \\
\hline 3001-3500 PLN (648-756 EUR) & 103 & 10.13 \\
\hline 3501-4500 PLN (756-972 EUR) & 78 & 7.67 \\
\hline$>4500$ PLN (972 EUR) & 121 & 11.90 \\
\hline Education & $n$ & $\%$ \\
\hline Primary/vocational & 425 & 41.75 \\
\hline Secondary & 356 & 34.97 \\
\hline Higher & 237 & 23.28 \\
\hline Professional status & $n$ & $\%$ \\
\hline Unemployed & 160 & 15.73 \\
\hline Full-time work & 567 & 55.75 \\
\hline Self-employed & 109 & 10.72 \\
\hline Part-time work/contract work & 95 & 9.34 \\
\hline Work and study & 45 & 4.42 \\
\hline Study & 41 & 4.03 \\
\hline
\end{tabular}

*SD—standard deviation; ** according to the National Polish Bank exchange rate as of 20 March 2021. Source: own research.

\subsection{Research Questionnaire}

The research questionnaire consisted of three parts:

- $\quad$ the first part included questions about the frequency of using various e-commerce solutions in the foodservices market-respondents were asked to specify the frequency of using these solutions on a scale of 0-6: 0 - do not use, $1-$ use once a year or less often, 2-use several times a year, 3-use once a month, 4-use several times a month, 5-use several times a week, 6-use every day;

- the second part included questions about the reasons for using or not using online food delivery options - the significance of the given reasons was assessed by the respondents on a scale of 1-5: 1 -invalid reason, 2-minor reason, 3-moderately important reason, 4-important reason, 5-very important reason;

- the third part included questions about the respondent's characteristics, taking into account demographic (gender, age, place of residence), economic (income), and social (education, professional status) factors, and selected lifestyle elements, such as social activity, physical activity and attention to proper nutrition (rating on a scale of 1-5: 
1-very low, 2-low, 3-medium, 4-high, 5-very high). To assess the quality of nutrition, in this part of the questionnaire respondents were also asked how many of the four products, commonly considered harmful to health (sugar, animal fats, salt and fast food), in their own opinion, they consume too much of (respondents could indicate one of five possible answers: none, one, two, three, all).

\subsection{Statistical Analysis}

Cluster analysis was carried out based on the frequency of using different kinds of e-commerce solutions in the foodservice market. The hierarchical method was used to isolate the clusters. The number of clusters was chosen based on a dendrogram. The obtained segments were statistically evaluated using the CCC (cubic clustering criteria) method and pseudo-F2 statistics. The results of both statistics confirmed that the obtained segments are well separated.

Respondent profiles were created, based on demographic characteristics such as gender, age, place of residence, education, employment status, and monthly income, to allow distinguishing separate segments. When creating consumer profiles, selected aspects of lifestyle (social activity, physical activity, nutrition) were also taken into account. Respondents' reasons for ordering food online and barriers limiting this activity, as well as preferences regarding dishes purchased online, were also included. Comparison of the features mentioned above in individual segments was ensured using the Chi2 independence test at the $p<0.05$ level of statistical significance. All calculations were made using the SAS 9.4 statistics package.

\section{Results}

\subsection{Frequency of Using E-Commerce Food Services}

Analysis of the frequency of using e-commerce food services showed that the most popular activities were: ordering food with delivery (average 3.47), searching for eateries (3.29), and browsing information about their offers (3.30). Slightly less frequently, the respondents used the internet to learn about other users' opinions of establishments (3.19). Participation in loyalty programs (2.99), and booking tables or ordering meals in a restaurant (average 2.33 and 2.20) were much less common.

Based on cluster analysis, three consumer segments with varying frequencies of using e-commerce offers were distinguished: frequent users (221), moderate users (400), and sporadic users (397).

Frequent users declared a statistically significant more frequent use of all the analyzed forms of foodservice e-commerce. In this group of respondents, the highest frequency was related to using loyalty programs (4.65) and browsing information about the offers (4.62), while the lowest, as in the case of all respondents, considered table and meals reservations (4.19 and 4.23). Moderate users most often used the internet to browse information about the offers (3.63), and least frequently to make reservations and participate in loyalty programs. Sporadic users used all forms of foodservice e-commerce least frequently, with the most common activity being online food delivery (2.42) (Table 2).

\subsection{Demographic and Economic Profile of the Segments}

As for demographic differences between the segments, frequent and moderate users were definitely younger than Sporadic users (35, 38, and 44 years old, respectively). Men were prevalent among frequent users $(56 \%)$, while women made up the majority of the remaining segments, especially Sporadic users (58\%). Considering the place of residence, frequent and moderate users were very similar in terms of the percentage of people living in rural areas and towns of various sizes, whereas sporadic users live mostly in rural areas, with a smaller percentage living in large and medium-sized towns. 
Table 2. Frequency * of using different forms of foodservice e-commerce offers.

\begin{tabular}{|c|c|c|c|c|}
\hline Specification & Total & $\begin{array}{l}\text { Frequent } \\
\text { Users }\end{array}$ & Moderate Users & Sporadic Users \\
\hline searching for eating establishments (cuisine, address, etc.) & 3.29 & $4.54^{\mathrm{a} * *}$ & $3.51^{\mathrm{b}}$ & $1.77^{\mathrm{c}}$ \\
\hline Browsing information about the offer of eateries & 3.30 & $4.62^{\mathrm{a}}$ & $3.63^{b}$ & $1.62^{\mathrm{c}}$ \\
\hline Checking other users' opinions about establishments & 3.19 & $4.55^{\mathrm{a}}$ & $3.51^{\mathrm{b}}$ & $1.51^{\mathrm{c}}$ \\
\hline Ordering meals with delivery & 3.47 & $4.52^{\mathrm{a}}$ & $3.52^{b}$ & $2.42^{\mathrm{c}}$ \\
\hline Booking a table at a restaurant & 2.33 & $4.19^{\mathrm{a}}$ & $2.09^{b}$ & $0.82^{\mathrm{c}}$ \\
\hline Ordering meals for pick-up & 2.20 & $4.23^{\mathrm{a}}$ & $1.88^{\mathrm{b}}$ & $0.66^{\mathrm{c}}$ \\
\hline Participating in loyalty programs & 2.99 & $4.65^{\mathrm{a}}$ & $2.85^{b}$ & $1.53^{\mathrm{c}}$ \\
\hline
\end{tabular}

* average frequency on a scale: 0 -do not use, 1 - use once a year or less often, 2 - use several times a year, 3 - use once a month on average, 4-use several times a month, 5-use several times a week, 6-use every day ** a , b c — means different letters are significantly different at 0.05 significance level. Source: own research.

Different levels of income also characterized the separate segments. Frequent users turned out to be much wealthier than the others-the largest portion of this group declared an income of 3001 PLN and more (43.5\%). Among the moderate users, the highest percentage of people, compared to other segments, declared an income in the range of 2500-3000 PLN (22.5\%). Sporadic users showed the highest percentage (24\%) of people with the lowest income (Table 3).

Table 3. Demographic and economic profile of the segments.

\begin{tabular}{cccc}
\hline Specification & $\begin{array}{c}\text { Frequent } \\
\text { Users }\end{array}$ & $\begin{array}{c}\text { Moderate } \\
\text { Users }\end{array}$ & $\begin{array}{c}\text { Sporadic } \\
\text { Users }\end{array}$ \\
\hline Age (years) average $p<0.0001$ & $35.46^{\mathrm{b} *}$ & $37.97^{\mathrm{b} *}$ & $43.73^{\mathrm{a} *}$ \\
\hline Woman & Sex $p=0.0042$ & \\
Man & 43.89 & 51.75 & 57.68 \\
& 56.11 & 48.25 & 42.32 \\
\hline Rural & Place of residence $p=0.0034$ & & \\
\hline City up to 50,000 residents & 36.65 & 36 & 73.07 \\
City 50,000-100,000 residents & 6.33 & 6.56 \\
City over 100,000 residents & 24.43 & 23.5 & 20.4 \\
\hline Up to 1500 PLN & 32.58 & 34.5 & 28.97 \\
1501-2500 PLN & Income $p<0.0001$ & 18.25 & 23.99 \\
2501-3000 PLN & 12.67 & 31.25 & 34.34 \\
3001-3500 PLN & 23.08 & 22.5 & 6.93 \\
3501-4500 PLN & 20.81 & 10.75 & 6.82 \\
>4500 PLN & 15.38 & 5.5 & 10.35 \\
\hline
\end{tabular}

*a, b-means entries with the same letter are not significantly different at 0.05 significance level. Source: own research.

\subsection{Social Profile of the Segments}

Analysis of the separate segments in terms of education showed that frequent users had the highest percentage of people with higher education $(29.4 \%)$, while sporadic users were dominated by people with elementary and vocational education $(46.4 \%)$. In terms of professional status, the highest percentage of unemployed people were found among sporadic users (25\%). This group also had a slightly higher percentage of people working part-time or on contract, and a lower share of people working and studying at the same time or only studying. In the moderate users group, there was a slightly higher percentage of people combining work with studying than in the other segments. Frequent users were distinguished by the highest percentage of people working full-time $(64 \%)$ and a slightly higher percentage of self-employed and studying persons (Table 4). 
Table 4. Social profile of the segments.

\begin{tabular}{cccc}
\hline & \multicolumn{3}{c}{ Education $p=0.0006$} \\
\hline Primary/vocational & 37.1 & 39.75 & 46.35 \\
Secondary & 33.48 & 34.5 & 36.27 \\
Higher & 29.41 & 25.75 & 17.38 \\
\hline & Professional status $p<0.0001$ & \\
\hline Unemployed & 6.79 & 11.25 & 25.25 \\
Full-time work & 63.8 & 59.5 & 47.47 \\
Self-employed & 12.22 & 10.5 & 10.1 \\
Part-time & 7.24 & 9.25 & 10.61 \\
work/contract work & 4.98 & 5.5 & 3.03 \\
Work and study & 4.98 & 4 & 3.54 \\
Study & & &
\end{tabular}

Source: own research.

\subsection{Lifestyle Profile of the Segments}

Analysis of differences between the selected segments in terms of social activity showed that respondents from the frequent users group are definitely the most social people - over $60 \%$ of them described their activity in this area as above average, including almost $25 \%$ as very high. Respectively, these percentages were $49 \%$ and $15 \%$ in the moderate users group, and $40 \%$ and $12 \%$ among sporadic users.

In the case of physical activity, frequent users also declared a more outstanding commitment: $23.5 \%$ of people in this segment reported as active beyond average, and $31 \%$ as very active or very highly active. The percentages were lower among moderate users $-21 \%$ and $13 \%$, and significantly lower among sporadic users- $-8 \%$ and $10 \%$.

When it comes to proper nutrition, sporadic and moderate users more often than frequent users declared that they care very little (5.3\%, $2.5 \%$ and $1.4 \%$ respectively) and little $(10.5 \%, 11.5 \%$ and $10 \%$ respectively) about this lifestyle aspect. The average correct approach to nutrition is related to the largest percentage of sporadic users $(41 \%)$ and a slightly smaller percentage of the moderate and frequent users segments (35\% and 36\%). A similar percentage of respondents declared outstanding care for proper nutrition in analyzed segments (34\%, 36\% and 33\% respectively), while very high care was characteristic of frequent users $(19 \%)$, slightly lower among moderate users $(15 \%)$, and the lowest for sporadic users $(10 \%)$.

To verify the respondents' declarations regarding their care for proper nutrition, a question about the consumption of the four products commonly considered harmful to health (sugar, animal fats, salt, and fast food) was introduced. The analysis of the obtained answers showed that though frequent users stated the most outstanding care for proper nutrition compared to other segments, they were also the most likely to indicate eating too much of two $(34 \%)$, three $(18 \%)$ and all $(18 \%)$ of the products included in the question. The answer "none of the mentioned products" was the most commonly indicated by sporadic users $(25.5 \%)$, whereas moderate users indicated the answer "one of the mentioned products" (24\%) most often (Table 5). 
Table 5. Segment profile according to selected lifestyle aspects.

\begin{tabular}{|c|c|c|c|}
\hline Specification & $\begin{array}{l}\text { Frequent } \\
\text { Users }\end{array}$ & $\begin{array}{l}\text { Moderate } \\
\text { Users }\end{array}$ & $\begin{array}{l}\text { Sporadic } \\
\text { Users }\end{array}$ \\
\hline \multicolumn{4}{|c|}{ Social activity $p<0.0001$} \\
\hline Very low & 0.9 & 2.26 & 5.3 \\
\hline Low & 11.31 & 10.3 & 11.36 \\
\hline Average & 27.15 & 38.69 & 43.18 \\
\hline High & 36.2 & 33.42 & 28.28 \\
\hline Very high & 24.43 & 15.33 & 11.87 \\
\hline \multicolumn{4}{|c|}{ Physical activity $p<0.0001$} \\
\hline Very low & 22.17 & 39.95 & 62.37 \\
\hline Low & 23.08 & 25.63 & 18.94 \\
\hline Average & 23.53 & 21.36 & 8.33 \\
\hline High & 18.11 & 7.04 & 5.05 \\
\hline Very high & 13.12 & 6.03 & 5.3 \\
\hline \multicolumn{4}{|c|}{ Care of proper nutrition $p=0.0158$} \\
\hline Very low & 1.36 & 2.51 & 5.3 \\
\hline Low & 9.95 & 11.56 & 10.35 \\
\hline Average & 35.75 & 34.92 & 40.91 \\
\hline High & 34.39 & 36.18 & 33.33 \\
\hline Very high & 18.55 & 14.82 & 10.1 \\
\hline \multicolumn{4}{|c|}{ Eating too much of the following products: salt, animal fat, sugar, fast food dishes $p=0.0320$} \\
\hline None of the mentioned & 12.33 & 19.89 & 25.51 \\
\hline One of the mentioned & 18.24 & 23.82 & 21.97 \\
\hline Two of the mentioned & 33.92 & 29.66 & 25.25 \\
\hline Three of the mentioned & 17.67 & 13.82 & 14.13 \\
\hline All of the mentioned & 17.84 & 12.81 & 13.14 \\
\hline
\end{tabular}

Source: own research.

\subsection{Reasons for Using and Not Using Online Orders with Delivery}

The most commonly used e-commerce food service in the general population was ordering food with delivery (Table 2). In the second section of the research questionnaire, respondents were asked about the reasons for using or not using online food ordering options.

All the reasons for online food delivery included in the question were more often indicated by frequent users than by the other segments, and the most important reasons for this group were: the possibility to choose from a wide range of dishes (77\% of answers 4-important reason and 5-very important reason), the fact that friends use online orders $(74 \%)$, and the pleasure experienced while using modern technologies $(72 \%)$. Not much less important (68-69\% of ratings 4 and 5) were such reasons as convenience, the loyalty programs participation possibilities, and saving time. A slightly lower percentage of frequent users indicated fashion in the use of new technologies $(66 \%)$ and saving money $(62 \%)$. With regard to people qualified as moderate users, the most important reasons for ordering food with delivery were a wide selection of dishes $(67 \%)$ and the pleasure of using new technologies $(70 \%)$. Convenience $(67 \%)$ came next, while the fact of doing it by friends and fashion were considered less important reasons ( $47 \%$ and $49 \%$ of ratings 4 and 5 , respectively). For sporadic users, the most important reason for using online delivery was, similarly to other segments, a wide range of dishes (63\%), while the second most important motivation was convenience (58\%).

The analysis of the significance of barriers in ordering food online showed that frequent users' activity was restricted mainly by the limited access to the internet (50\% of the ratings are 4 and 5) and the lack of proper hardware (47\%). The lack of skills to order the dishes $(40 \%)$ also turned out to be a significant barrier, while the least important factors were long delivery times $(29 \%)$ and aversion to new technologies $(27 \%)$. For moderate users, the main reason for not ordering online was the lack of proper hardware (62\%). 
Lack of skills to order the dishes was also of great importance (55\%) as well as negative personal experiences (52\%), a negative attitude to new technologies $(51 \%)$ and friends opinions $(50 \%)$. The percentage of moderate users who indicated difficulties with limited internet access as the reason for not using online orders was slightly lower than among frequent users $(48 \%)$. The remaining reasons for not using online food delivery cited as very important or important, were considered by a more significant percentage of moderate users than frequent users, and the most considerable difference (14 pp) was recorded in the case of the aversion to new technologies. Among sporadic users, the percentage of citing all of the reasons for not using online orders was higher than in the other segments, and the largest percentage of representatives of this group indicated such reasons as the aversion to new technologies $(66 \%)$, inability to place an order $(64 \%)$, and the lack of appropriate hardware (63\%) (Table 6).

Table 6. Reasons to use or not use online orders with delivery.

\begin{tabular}{|c|c|c|c|c|}
\hline Specification & $\begin{array}{l}\text { Frequent } \\
\text { Users }\end{array}$ & $\begin{array}{l}\text { Moderate } \\
\text { Users }\end{array}$ & $\begin{array}{l}\text { Sporadic } \\
\text { Users }\end{array}$ & $p$ \\
\hline \multicolumn{5}{|c|}{ Reasons to use * } \\
\hline Saving time & 68.33 & 41.50 & 33.50 & 0.0021 \\
\hline Saving money & 62.00 & 35.71 & 35.25 & $<0.0001$ \\
\hline Arranging a meal in a convenient way & 68.78 & 66.75 & 57.93 & 0.0130 \\
\hline Wide range of dishes & 76.90 & 67.25 & 63.21 & $<0.0001$ \\
\hline The pleasure of using new technologies & 71.95 & 69.81 & 40.13 & $<0.0001$ \\
\hline Friends ordering food online & 74.22 & 46.81 & 45.33 & $<0.0001$ \\
\hline Opportunity to participate in loyalty programs & 68.77 & 45.25 & 35.02 & $<0.0001$ \\
\hline Fashion for the use of new technologies & 65.61 & 49.75 & 45.10 & $<0.0001$ \\
\hline \multicolumn{5}{|c|}{ Reasons to not use * } \\
\hline Long delivery time & 28.96 & 35.50 & 37.28 & $<0.0001$ \\
\hline Low quality of the delivered dishes & 30.32 & 37.53 & 46.25 & 0.0004 \\
\hline High delivery costs & 34.39 & 41.25 & 43.83 & $<0.0001$ \\
\hline Negative feedback from friends & 34.84 & 49.75 & 49.85 & $<0.0001$ \\
\hline Negative own experiences & 36.64 & 51.75 & 54.16 & $<0.0001$ \\
\hline Limited internet access & 49.81 & 48.25 & 51.15 & 0.0003 \\
\hline Lack of proper hardwere & 46.61 & 61.75 & 62.75 & $<0.0001$ \\
\hline Lack of ordering skills & 39.82 & 55.19 & 64.00 & $<0.0001$ \\
\hline Aversion to new technologies & 26.69 & 50.75 & 65.75 & $<0.0001$ \\
\hline Fear of the order not being delivered & 34.38 & 40.81 & 48.50 & $<0.0001$ \\
\hline
\end{tabular}

* the percentage of grades 4 and 5 on the scale: 1—invalid reason, 2—not important reason, 3-moderately important reason, 4-important reason, 5-very important reason. Source: own research.

\subsection{Dishes Ordered Online}

Respondents were also asked to indicate which dishes they ordered online most often. The results show that frequent users ordered online dishes from almost all the analyzed cuisines more often than other respondents, with the exception of Polish cuisine (the most recognized and popular) and vegetarian dishes (the least popular), which were most often ordered by moderate users. A particularly large difference was found in the case of Italian cuisine, the most typical example of which is pizza (14.8 pp between frequent and moderate users and $8.3 \mathrm{pp}$ between frequent and sporadic users). Significant differences were also found in the case of American cuisine, mostly recognized in Poland for hamburgers, fries, and hot dogs (11.5 pp between frequent and moderate users and $10.2 \mathrm{pp}$ between frequent and sporadic users), and Polish cuisine (13.2 pp between frequent and moderate users and $6.5 \mathrm{pp}$ between frequent and sporadic users) (Table 7). 
Table 7. Dishes ordered online.

\begin{tabular}{ccccc}
\hline Specification & $\begin{array}{c}\text { Frequent } \\
\text { Users }\end{array}$ & $\begin{array}{c}\text { Moderate } \\
\text { Users }\end{array}$ & $\begin{array}{c}\text { Sporadic } \\
\text { Users }\end{array}$ & $p$ \\
\hline Italian cuisine & 47.06 & 32.25 & 38.79 & 0.0012 \\
American cuisine & 56.03 & 44.50 & 45.84 & 0.0003 \\
Vegetarian cuisine & 7.69 & 8.23 & 7.31 & 0.0310 \\
Polish cuisine & 56.55 & 69.77 & 63.00 & 0.0016 \\
Japanese cuisine & 14.03 & 10.75 & 7.05 & 0.0179 \\
Asian cuisine & 18.14 & 12.50 & 13.00 & 0.0079 \\
\hline
\end{tabular}

Source: own research.

\section{Discussion}

The findings of the research fully confirmed the assumption formulated under the first hypothesis, that in terms of demographic and social characteristic, the digital foodservice customer (represented in the segmentation by frequent users) does not significantly differ from the characteristics of e-consumers stated in the research carried out so far. A typical foodservice e-commerce customer is slightly more often a man, a relatively young person, which was also stated, in relation to e-consumers, by Jaciow et al. [28] and Brown et al. [32], as well as by Keeble et al. [63], in relation to online food delivery users. The e-catering consumer more often lives in a large or medium-sized city and has a permanent job and university education, which is consistent with the results of research by Jaciow et al. [28] and Li et al. [44]. The economic situation of such a customer, similar to other e-consumers, is above average, which was also noted in the studies by Tan [46] and Jaciow et al. [28].

In terms of lifestyle, the e-customer of a food service is a socially active person and does not avoid physical activity. In terms of importance attached to proper nutrition, frequent users of foodservice e-commerce, on one hand, declared the most outstanding care for proper nutrition, compared to other segments, but on the other hand, they confirmed excessive consumption of products commonly considered to be harmful to health the most frequently. This contradiction between intentions and the actually implemented nutrition can be partially explained by the theory of planned behavior (TPB) [92], according to which the basis for human behavior is an intention, but its translation into action is influenced mainly by the individual's own effectiveness, i.e., a belief that they have sufficient resources to deal with obstacles encountered in carrying out the intended behavior.

Information on the nutritional behavior of frequent users is consistent with the observations and suggestions of other researchers, according to which the use of catering services may have an adverse effect on health $[21,23,24]$. Taking into account the dynamic development of the gastronomic market and online food delivery offers, the obtained data should be alarming. They show that amongst the dishes most frequently ordered by this group of consumers are Italian (pizza, spaghetti) and American dishes (burgers, fries, and hot dogs), and it is well known that excessive consumption of fast food meals promotes obesity and is a causative factor for many diseases [93]. The above observations prove the correctness of the fifth hypothesis, according to which people who frequently order food online are characterized by a worse quality of nutrition.

The most commonly used e-commerce food service in the general study population was ordering food with delivery, which confirms the validity of the second hypothesis. Analysis of the reasons for ordering food online showed that, for frequent users, the reasons for the most significant importance were the possibility to choose from a wide range of dishes, the fact that friends use online orders, and the pleasure they experience while using modern technologies. The influence of the factors mentioned above was also found in studies on e-customers' behavior. The motivational significance of the freedom of choice was also stated by Thomson et al. [48], the influence of social environment on e-consumers' behavior was noted in the studies by Huang and Yang [94], while the aspect of pleasure encouraging e-shopping was confirmed by the results of Kim [49] and Kim and Peterson [50]. No less important were reasons for ordering food online such as convenience, 
saving time as well as possibility of using loyalty programs, which was also found by examining the purchasing motivations of e-consumers [48-50,54].

The reasons for ordering food online stated above partially proved the validity of the third hypothesis, according to which the primary motivator for ordering food online is convenience. This hypothesis also suggested that the fundamental limitation for online orders are technical issues related to internet access and a lack of communications devices.

The results fully confirmed these assumptions. In addition to the limitations mentioned above, the lack of skills to order dishes online was a significant barrier, while the least limiting factors were long delivery times and high delivery costs. The analysis of the limitations for using online orders in the moderate and sporadic users segments turned out to be interesting - compared to frequent users, these respondents were relatively more discouraged from online shopping by an aversion to new technologies, bad previous experiences and negative influence from friends, which was also stated by Das [95]. Important barriers for both segments also included lack of skills and hardware. Sporadic users were also discouraged by risk of nondelivery of the order and its possible low quality, which were previously noted in the research by Huang et al. [38], Kolsaker et al. [39] and Das [95].

The fourth research hypothesis assumed that frequent users, in comparison with moderate and sporadic users, are the most socially active people and the most committed to s-commerce activities. The results fully confirm this assumption with three findings: first, the vast majority of participants in this segment rated their social activity as "high" and "very high"; second, frequent users much more often use forms of foodservice ecommerce such as browsing menus, checking other user opinions about establishments and participating in loyalty programs; and third, when using online ordering, reasons such as friends' opinions, fashion and enjoyment of new technologies are more important for them than for other segments.

Obtained results are supported by the results of previous studies which have found that social activity results in greater openness to new technologies $[96,97]$ and promotes trust in e-commerce companies [98]; it is also a key determinant of online community participation intentions and behaviors [65]. Earlier studies also found the prevalence of information sharing and use within online communities [99-102]. According to studies by Aladwani [101], Sheikh et al. [103], Maia et al. [104], and Hajli et al. [65], s-commerce activity can have a significant impact on purchase intentions and buying behavior, although findings by Molinillo et al. [105] and Hsu et al. [106] did not support this thesis.

\section{Conclusions}

With the rapid growth of e-consumption in the foodservice market during the COVID19 pandemic, knowledge of the characteristics of the e-consumer is an essential part of building the marketing strategy of foodservice companies in the new post-COVID market reality.

The results of the research have demonstrated that a typical consumer of e-foodservice offers is more often a young and educated man with a permanent job and a higher than average income, living in a large or medium city. The most common activities for such an individual are participating in loyalty programs, browsing information about the offers of eateries, searching for eating establishments, checking other users' opinions about establishments, and ordering meals with delivery. As the most important reasons for using online food delivery, they cite the wide selection of dishes, the fact that friends use online orders, and the pleasure experienced while using modern technologies. The activity of a digital foodservices customer in this area is mainly limited by problems with access to the internet and the lack of appropriate technological devices. Taking into account the lifestyle aspects, it was found that a foodservice e-customer is a physically and socially and active person, showing utmost commitment to s-commerce activities, which influences their purchasing intentions and behaviors.

The study also showed that frequent e-offer users, in their own opinion, care about proper nutrition, but despite such declarations, the quality of their nutrition is inferior to 
the quality of nutrition of people less frequently using e-commerce offers in foodservices market. Given the fast growth of interest in such offers and the fact that it mainly concerns young consumers, the question arises of the health consequences of this phenomenon and the possibility of preventing its potential negative effects.

The findings in this study offer new insights and practical implications for the development of the foodservice market. The strength of this study is the comprehensive presentation of the profile of e-foodservice consumers, with the consideration of selected aspects of lifestyle, including quality of nutrition. It is worth stressing that the study results captured an inconsistency between declared care for proper nutrition and the frequency of consumption of food considered as not healthy. This leads to the conclusion that the development of e-foodservice offers (including online delivery) should not only take into account the technological facilitation, convenience and attractiveness of these solutions, but should also do more to support rational and sustainable food choices. In the context of the COVID-19 pandemic and limited face-to-face contact impacting the social aspects of gastronomy, the inclusion of social commerce issues in the research can be considered as an added value of this study.

This study also has some limitations that can be eliminated in future studies. For example, it would be worthwhile to highlight the nutrition quality issues of e-foodservice consumers in more detail. It would also be desirable to develop s-commerce issues, focusing on the influence of these functionalities on the consumer's decision making process. Due to the growing importance and need of sustainable development, it is also worth checking the preference of e-foodservice consumers for such solutions as ecological packaging, food waste, environmentally friendly delivery methods transport and implementation of other sustainable solutions by the catering facility in future studies.

It should be emphasized that this study concerns only the Polish market, so it would be advisable to carry out similar research in other countries to confirm the obtained results or to present a different perspective on the issue of the e-foodservice consumer behavior.

Author Contributions: Conceptualization: I.K., D.S. and J.G; methodology, J.G.; software, J.G.; validation, I.K. and D.S.; formal analysis, J.G.; investigation, A.T.-K.; resources, I.K., D.S. and E.Z.; data curation, J.G.; writing-original draft preparation, I.K.; writing—review and editing, I.K., E.Z., J.G., D.S. and A.T.-K., visualization, J.G.; supervision, I.K. and D.S.; project administration, A.T.-K.; funding acquisition, A.T.-K. All authors have read and agreed to the published version of the manuscript.

Funding: The research was financed with funds of Faulty of Human Nutrition, Warsaw University of Life Sciences (WULS) for scientific research, no.

Institutional Review Board Statement: The study was conducted according to the guidelines of the Declaration of Helsinki. The personal information and data of the participants were anonymous according to the General Data Protection Regulation of the European Parliament (GDPR 679/2016). The survey did not require approval by the ethics committee because of the anonymous nature of the online survey and impossibility of tracking sensitive personal data, additionally the CAWI survey was conducted by professional company certified to conduct research in accordance with industry and ethical standards.

Informed Consent Statement: Informed consent was obtained from all subjects involved in the study.

Data Availability Statement: The authors confirm that the datasets analyzed during the study are available from the corresponding author upon reasonable request.

Conflicts of Interest: The authors declare no conflict of interest.

\section{References}

1. Golpek, F. Service Sector and Technological Developments. Procedia Soc. Behav. Sci. 2015, 181, 125-130. [CrossRef]

2. Jalil, M.S. E-service Innovation: A Case Study of Shohoz.com. Procedia Soc. Behav. Sci. 2016, 224, 531-539. [CrossRef]

3. Oronsky, C.R.; Chathoth, P.K. An exploratory study examining information technology adoption and implementation in fullservice restaurant firms. Int. J. Hosp. Manag. 2007, 26, 941-956. [CrossRef]

4. Olsen, M.D.; Connolly, D.J. Experience-based Travel. Cornell Hotel Restaur. Adm. Q. 2000, 41, 30-40. [CrossRef] 
5. Voytovych, N.; Polyak, Y. The marketing innovation and the innovation technology in food industry enterprises. Sci. Messenger LNU Vet. Med. Biotechnol. 2019, 21, 9-14. [CrossRef]

6. Slack, N.; Chambers, S.; Johnston, R. Operations Management; Pearson Education: London, UK, 2010.

7. Lee, S.; Barker, S.; Kandampully, J. Technology, service quality, and customer loyalty in hotels: Australian managerial perspectives. Manag. Serv. Qual. Int. J. 2003, 13, 423-432. [CrossRef]

8. Kim, W.G.; Ham, S. The Impact of Information Technology Implementation on Service Quality in the Hotel Industry. Inf. Technol. Hosp. 2006, 4, 143-151. [CrossRef]

9. Prasad, M.; Scornavacca, E.; Lehmann, H. Using Wireless Personal Digital Assistants in a Restaurant: Impact and Perceived Benefits. In Proceedings of the International Conference on Mobile Business (ICMB'05), Sydney, Australia, 11-13 July 2005; pp. 69-74.

10. Radosevic, S.; Stancova, K.C. Internationalising Smart Specialisation: Assessment and Issues in the Case of EU New Member States. J. Knowl. Econ. 2015, 9, 263-293. [CrossRef]

11. Davis, B.; Lockwood, A.; Pantelidis, I.; Alco, P. Food and Beverage Management; Routledge: London, UK, 2013.

12. Riley, M. Food and beverage management. Int. J. Contemp. Hosp. Manag. 2005, 17, 88-93. [CrossRef]

13. Maroto, A.; Rubalcaba, L. Services productivity revisited. Serv. Ind. J. 2008, 28, 337-353. [CrossRef]

14. Pilato, M.; Séraphin, H.; Bellia, C.; Căescu, S. Challenging the Negative Image of Destinations at Pre-visit Stage Using Food and Food Events as an Educational Tool: The Case of Romania. J. Emerg. Trends Mark. Manag. 2017, 1, 35-45.

15. Rathnayaka, U. Role of Digital Marketing in Retail Fashion Industry: A Synthesis of the Theory and the Practice. J. Account. Mark. 2018, 7, 279. [CrossRef]

16. Isazadeh, A. Information society: Concepts and definitions. WSEAS Trans. Syst. 2004, 6, 1-4.

17. Isazadeh, A. Prospectives information society: Optimizing management strategies. Appl. Comput. Math 2006, 5, $227-232$.

18. Wang, X.; Tajvidi, M.; Lin, X.; Hajli, N. Towards an Ethical and Trustworthy Social Commerce Community for Brand Value Co-creation: A Trust-Commitment Perspective. J. Bus. Ethics 2020, 167, 137-152. [CrossRef]

19. Keke, C.; Yana, H. Research advancement of association of eating out of home with health. Food Nutr. China 2014, 20 , 67-71. [CrossRef]

20. Lachat, C.; Nago, H.E.S.; Verstraeten, R.; Roberfroid, D.; Van Camp, J.; Kolsteren, P. Eating out of home and its association with dietary intake: A systematic review of the evidence. Obes. Rev. 2011, 13, 329-346. [CrossRef] [PubMed]

21. Mancino, L.; Todd, J.; Lin, B.-H. Separating what we eat from where: Measuring the effect of food away from home on diet quality. Food Policy 2009, 34, 557-562. [CrossRef]

22. Affenito, S.G.; Franko, D.L.; Striegel-Moore, R.H.; Thompson, U. Behavioral Determinants of Obesity: Research Findings and Policy Implications. J. Obes. 2012, 2012, 150732. [CrossRef]

23. Todd, J.E.; Mancino, L.; Lin, B.-H. The Impact of Food Away from Home on Adult Diet Quality. Available online: https: / / www.ers.usda.gov/webdocs/publications/46352/8170_err90_1_.pdf (accessed on 15 January 2021).

24. Stephens, J.; Miller, H.; Militello, L. Food Delivery Apps and the Negative Health Impacts for Americans. Front. Nutr. 2020, 7, 14. [CrossRef]

25. Dsouza, D.; Sharma, D. Online food delivery portals during COVID-19 times: An analysis of changing consumer behavior and expectations. Int. J. Innov. Sci. 2021, 13, 218-232. [CrossRef]

26. Mehrolia, S.; Alagarsamy, S.; Solaikutty, V.M. Customers response to online food delivery services during COVID-19 outbreak using binary logistic regression. Int. J. Consum. Stud. 2021, 45, 396-408. [CrossRef] [PubMed]

27. Alaimo, L.S.; Fiore, M.; Galati, A. How the Covid-19 Pandemic Is Changing Online Food Shopping Human Behaviour in Italy. Sustainability 2020, 12, 9594. [CrossRef]

28. Jaciow, M.; Wolny, R.; Stolecka-Makowska, A.; Świątek, A. E-Consumer in Europe: Comparative Analysis of Behaviours; Helion: Gliwice, Poland, 2013.

29. Napoli, N.; Shah, K.; Waters, D.L.; Sinacore, D.R.; Qualls, C.; Villareal, D.T. Effect of weight loss, exercise, or both on cognition and quality of life in obese older adults. Am. J. Clin. Nutr. 2014, 100, 189-198. [CrossRef]

30. Dennis, C.; Fenech, T.; Merrilees, B. E-Retailing; Routledge: London, UK, 2004.

31. Dennis, C.; Harris, L. Marketing the E-Business; Routledge: London, UK, 2007.

32. Brown, M.; Pope, N.; Voges, K. Buying or browsing? Eur. J. Mark. 2003, 37, 1666-1684. [CrossRef]

33. Wolfinbarger, M.; Gilly, M.C. eTailQ: Dimensionalizing, measuring and predicting etail quality. J. Retail. 2003, 79, 183-198. [CrossRef]

34. Xia, L. Affect as information: The role of affect in consumer online behaviors. Adv. Consum. Res. 2002, $29,93-99$.

35. Jayawardhena, C.; Wright, L.T. Consumers online: Intentions, orientations and segmentation. Int. J. Retail Distrib. Manag. 2007, 35, 515-526. [CrossRef]

36. Liu, C.; Xie, B.; Chou, C.-P.; Koprowski, C.; Zhou, D.; Palmer, P.; Sun, P.; Guo, Q.; Duan, L.; Sun, X.; et al. Perceived stress, depression and food consumption frequency in the college students of China seven cities. Physiol. Behav. 2007, 92, 748-754. [CrossRef]

37. Bhatnagar, A.; Ghose, S. Online information search termination patterns across product categories and consumer demographics. J. Retail. 2004, 80, 221-228. [CrossRef] 
38. Huang, W.-Y.; Schrank, H.; Dubinsky, A.J. Effect of brand name on consumers' risk perceptions of online shopping. J. Consum. Behav. 2004, 4, 40-50. [CrossRef]

39. Kolsaker, A.; Lee-Kelley, L.; Choy, P.C. The reluctant Hong Kong consumer: Purchasing travel online. Int. J. Consum. Stud. 2004, 28, 295-304. [CrossRef]

40. Zhang, G.M.P. User expectations and rankings of quality factors in different web site domains. Int. J. Electron. Commer. 2001, 6, 9-33.

41. Stern, B.B.; Stafford, M.R. Individual and social determinants of winning bids in online auctions. J. Consum. Behav. 2006, 5, 43-55. [CrossRef]

42. Liao, Z.; Cheung, M.T. Internet-based e-banking and consumer attitudes: An empirical study. Inf. Manag. 2002, 39, 283-295. [CrossRef]

43. Korgaonkar, P.K.; Wolin, L.D. A multivariate analysis of web usage. J. Advert. Res. 1999, 39, $53-68$.

44. Li, H.; Kuo, C.; Rusell, M.G. The Impact of Perceived Channel Utilities, Shopping Orientations, and Demographics on the Consumer's Online Buying Behavior. J. Comput. Commun. 2006, 5, 521. [CrossRef]

45. Vrechopoulos, A.P.; Siomkos, G.J.; Doukidis, G.I. Internet shopping adoption by Greek consumers. Eur. J. Innov. Manag. 2001, 4, 142-153. [CrossRef]

46. Tan, S.J. Strategies for reducing consumers' risk aversion in Internet shopping. J. Consum. Mark. 1999, 16, 163-180.

47. Siu, N.Y.-M.; Cheng, M.M.-S. A Study of the Expected Adoption of Online Shopping-The Case of Hong Kong. J. Int. Consum. Mark. 2001, 13, 87-106. [CrossRef]

48. Thomson, E.S.; Laing, A.W. “The Net Generation": Children and Young People, the Internet and Online Shopping. J. Mark. Manag. 2003, 19, 491-512. [CrossRef]

49. Kim, Y. Trust in health information websites: A systematic literature review on the antecedents of trust. Health Inform. J. 2016, 22, 355-369. [CrossRef]

50. Kim, Y.; Peterson, R.A. A Meta-analysis of Online Trust Relationships in E-commerce. J. Interact. Mark. 2017, 38, 44-54. [CrossRef]

51. Parasuraman, A. Technology Readiness Index (Tri): A Multiple-Item scale to measure readiness to embrace new technologies. J. Serv. Res. 2000, 2, 307-320. [CrossRef]

52. Rosenbaum, M.S.; Wong, I.A. If you install it, will they use it? Understanding why hospitality customers take "technological pauses" from self-service technology. J. Bus. Res. 2015, 68, 1862-1868. [CrossRef]

53. Shergill, G.S.; Chen, Z. Shopping on the Internet-Online Purchase Behavior of New Zealand Consumers. J. Internet Commer. 2004, 3, 61-77. [CrossRef]

54. Chu, C.; Lu, H. Factors influencing online music purchase intention in Taiwan. Internet Res. 2007, 17, 139-155. [CrossRef]

55. Kim, S.; Stoel, L. Apparel retailers: Website quality dimensions and satisfaction. J. Retail. Consum. Serv. 2004, 11, 109-117. [CrossRef]

56. Liu, X.; He, M.; Gao, F.; Xie, P. An empirical study of online shopping customer satisfaction in China: A holistic perspective. Int. J. Retail. Distrib. Manag. 2008, 36, 919-940. [CrossRef]

57. Aren, S.; Güzel, M.; Kabadayı, E.; Alpkan, L. Factors Affecting Repurchase Intention to Shop at the Same Website. Procedia Soc. Behav. Sci. 2013, 99, 536-544. [CrossRef]

58. Donthu, N.; Garcia, A. The internet shopper. J. Advert. Res. 1999, 39, 52-58.

59. Kau, A.K.; Tang, Y.E.; Ghose, S. Typology of online shoppers. J. Consum. Mark. 2003, 20, 139-156. [CrossRef]

60. Rohm, A.J.; Swaminathan, V. A typology of online shoppers based on shopping motivations. J. Bus. Res. 2004, 57, 748-757. [CrossRef]

61. Cristobal-Fransi, E.; Marimon, F.; Daries, N.; Montagut, Y. Spanish E-Consumer Segmentation and Positioning in Virtual Supermarkets Sector. Int. J. Mark. Stud. 2011, 3. [CrossRef]

62. Yeo, V.C.S.; Goh, S.-K.; Rezaei, S. Consumer experiences, attitude and behavioral intention toward online food delivery (OFD) services. J. Retail. Consum. Serv. 2017, 35, 150-162. [CrossRef]

63. Keeble, M.; Adams, J.; Sacks, G.; Vanderlee, L.; White, C.M.; Hammond, D.; Burgoine, T. Use of Online Food Delivery Services to Order Food Prepared Away-From-Home and Associated Sociodemographic Characteristics: A Cross-Sectional, Multi-Country Analysis. Int. J. Environ. Res. Public Health 2020, 17, 5190. [CrossRef]

64. Chung, N.; Song, H.G.; Lee, H. Consumers' impulsive buying behavior of restaurant products in social commerce. Int. J. Contemp. Hosp. Manag. 2017, 29, 709-731. [CrossRef]

65. Hajli, N.; Sims, J.; Zadeh, A.H.; Richard, M.-O. A social commerce investigation of the role of trust in a social networking site on purchase intentions. J. Bus. Res. 2017, 71, 133-141. [CrossRef]

66. Li, C.-Y. How social commerce constructs influence customers' social shopping intention? An empirical study of a social commerce website. Technol. Forecast. Soc. Chang. 2019, 144, 282-294. [CrossRef]

67. Gibreel, O.; AlOtaibi, D.A.; Altmann, J. Social commerce development in emerging markets. Electron. Commer. Res. Appl. 2018, 27, 152-162. [CrossRef]

68. Turban, E.; Bolloju, N.; Liang, T. Social commerce: An e-commerce perspective. In Proceedings of the International Conference on Electronic Commerce: Roadmap for the Future of Electronic Business (ICEC 2010), Seoul, Korea, 8-11 September 2010; pp. 33-42.

69. Chen, X.; Li, Y.; Davison, R.M.; Liu, Y. The impact of imitation on Chinese social commerce buyers' purchase behavior: The moderating role of uncertainty. Int. J. Inf. Manag. 2021, 56, 102262. [CrossRef] 
70. Lee, S.W.; Sung, H.J.; Jeon, H.M. Determinants of Continuous Intention on Food Delivery Apps: Extending UTAUT2 with Information Quality. Sustainability 2019, 11, 3141. [CrossRef]

71. Lin, J.; Guo, J.; Turel, O.; Liu, S. Purchasing organic food with social commerce: An integrated food-technology consumption values perspective. Int. J. Inf. Manag. 2020, 51, 102033. [CrossRef]

72. Wang, Y.; Herrando, C. Does privacy assurance on social commerce sites matter to millennials? Int. J. Inf. Manag. 2019, 44, 164-177. [CrossRef]

73. Han, H.; Xu, H.; Chen, H. Social commerce: A systematic review and data synthesis. Electron. Commer. Res. Appl. 2018, 30, 38-50. [CrossRef]

74. Wang, Y.; Wang, J.; Yao, T.; Li, M.; Wang, X. How does social support promote consumers' engagement in the social commerce community? The mediating effect of consumer involvement. Inf. Process. Manag. 2020, 57, 102272. [CrossRef]

75. Meilatinova, N. Social commerce: Factors affecting customer repurchase and word-of-mouth intentions. Int. J. Inf. Manag. 2021, 57, 102300. [CrossRef]

76. Smith, D.; Menon, S.; Sivakumar, K. Online peer and editorial recommendations, trust, and choice in virtual markets. J. Interact. Mark. 2005, 19, 15-37. [CrossRef]

77. Nakayama, M.; Wan, Y. The cultural impact on social commerce: A sentiment analysis on Yelp ethnic restaurant reviews. Inf. Manag. 2019, 56, 271-279. [CrossRef]

78. Kim, S.-B.; Sun, K.-A.; Kim, D.-Y. The Influence of Consumer Value-Based Factors on Attitude-Behavioral Intention in Social Commerce: The Differences between High- and Low-Technology Experience Groups. J. Travel Tour. Mark. 2013, 30, 108-125. [CrossRef]

79. Elghannam, A.; Escribano, M.; Mesias, F. Can social networks contribute to the development of short supply chains in the Spanish agri-food sector? New Mediterr. 2017, 16, 36-42.

80. Digital Economy and Society Index (DESI) 2019 Country Report Poland. Available online: https://digital-strategy.ec.europa.eu/ en/policies / desi-poland (accessed on 16 December 2020).

81. E-commerce in Poland 2018, Gemius Report, 15+ Internet User CAWI Survey. Available online: https://www.gemius.pl/ wszystkie-artykuly-aktualnosci/raport-e-commerce.html (accessed on 16 December 2020).

82. Społeczeństwo Informacyjne w Polsce. Wyniki Badań Statystycznych z lat 2014-2018, GUS, Warszawa Szczecin. 2018. Available online: https://stat.gov.pl/download/gfx/portalinformacyjny/pl/defaultaktualnosci/5497/1/12/1/spoleczenstwo_ informacyjne_w_polsce._wyniki_badan_statystycznych_z_lat_2014-2018.pdf (accessed on 16 December 2020).

83. Van den Bergh, J.; Kerkstoel, G.K.M.; Behrer, M. Jak Kreować Marki, Które Pokocha Pokolenie Y; Edgard: Northampton, MA, USA, 2012.

84. Williams, K.C.; Page, R.A. Marketing to the generations. J. Behav. Stud. Bus. 2011, 3, 37-53.

85. Das, S.; Ghose, D. Influence of online food delivery apps on the operations of the restaurant business. Int. J. Sci. Technol. Res. 2019, 8, 1372-1377.

86. Li, C.; Mirosa, M.; Bremer, P. Review of Online Food Delivery Platforms and their Impacts on Sustainability. Sustainability 2020, 12, 5528. [CrossRef]

87. Foodservice Market in Poland Report 2019. Available online: http:/ /www.horecanet.pl/rynek-gastronomiczny-w-polsce-raport/ (accessed on 20 December 2020).

88. Foodservice Market in Poland Report 2020. Available online: http://www.horecanet.pl/rynek-gastronomiczny-w-polsce-raport/ (accessed on 13 March 2021).

89. Poland on a Plate 2019. Available online: https:/ / warszawa.naszemiasto.pl/polska-na-talerzu-prawie-kazdy-polak-chodzi-dorestauracji/ar/c3-7372523 (accessed on 15 January 2021).

90. Clik and Eat 2018. Polish Food Delivery Market Report. Available online: https://media.pizzaportal.pl/pliki/PizzaPortal.pl_ Click_and_eat_2018.pdf (accessed on 15 March 2021).

91. Online Food Delivery in Poland 2020. Available online: https://www.statista.com/outlook/374/146/online-food-delivery/ poland (accessed on 15 March 2021).

92. Ajzen, I. The theory of planned behavior. Organ. Behav. Hum. Decis. Process. 1991, 50, 179-211. [CrossRef]

93. Kovic, Y.; Noel, J.K.; Ungemack, J.A.; Burleson, J.A. The impact of junk food marketing regulations on food sales: An ecological study. Obes. Rev. 2018, 19, 761-769. [CrossRef]

94. Huang, J.-H.; Yang, Y.-C. The Relationship between Personality Traits and Online Shopping Motivations. Soc. Behav. Pers. Int. J. 2010, 38, 673-679. [CrossRef]

95. Das, J. Consumer perception towards online food ordering and delivery services: An empirical study. J. Manag. 2018, 5, 155-163.

96. Cheung, C.; Shen, X.-L.; Lee, Z.W.; Chan, T.K. Promoting sales of online games through customer engagement. Electron. Commer. Res. Appl. 2015, 14, 241-250. [CrossRef]

97. Shanmugam, M.; Sun, S.; Amidi, A.; Khani, F.; Khani, F. The applications of social commerce constructs. Int. J. Inf. Manag. 2016, 36, 425-432. [CrossRef]

98. Gundlach, G.T.; Murphy, P.E. Ethical and Legal Foundations of Relational Marketing Exchanges. J. Mark. 1993, 57, 35. [CrossRef]

99. Hajli, N.; Lin, X. Exploring the Security of Information Sharing on Social Networking Sites: The Role of Perceived Control of Information. J. Bus. Ethics 2016, 133, 111-123. [CrossRef] 
100. Busalim, A.H.; Hussin, A.R.C.; Iahad, N.A. Factors Influencing Customer Engagement in Social Commerce Websites: A Systematic Literature Review. J. Theor. Appl. Electron. Commer. Res. 2019, 14, 1-14. [CrossRef]

101. Aladwani, A. A quality-facilitated socialization model of social commerce decisions. Int. J. Inf. Manag. 2018, 40, 1-7. [CrossRef]

102. Molinillo, S.; Anaya-Sánchez, R.; Liébana-Cabanillas, F. Analyzing the effect of social support and community factors on customer engagement and its impact on loyalty behaviors toward social commerce websites. Comput. Hum. Behav. 2020, 108, 105980. [CrossRef]

103. Sheikh, Z.; Yezheng, L.; Islam, T.; Hameed, Z.; Khan, I.U. Impact of social commerce constructs and social support on social commerce intentions. Inf. Technol. People 2019, 32, 68-93. [CrossRef]

104. Maia, C.; Lunardi, G.; Longaray, A.; Munhoz, P. Factors and characteristics that influence consumers' participation in social commerce. Rev. Gest. 2018, 25, 194-211. [CrossRef]

105. Molinillo, S.; Liébana-Cabanillas, F.; Anaya-Sánchez, R. A Social Commerce Intention Model for Traditional E-Commerce Sites. J. Theor. Appl. Electron. Commer. Res. 2018, 13, 80-93. [CrossRef]

106. Hsu, C.-L.; Chen, M.-C.; Kikuchi, K.; Machida, I. Elucidating the determinants of purchase intention toward social shopping sites: A comparative study of Taiwan and Japan. Telemat. Inform. 2017, 34, 326-338. [CrossRef] 